\title{
Basic Concepts in Information Literacy
}

\section{Abstract} \\ After completing this learning unit, you will be able to: \\ - Identify the meaning of the term information literacy; \\ - Identify general competences in information literacy; \\ - Evaluate critical standards of information literacy; \\ - Compare existing models in information literacy.
}

\section{Keywords}

Information society $\cdot$ Information explosion - Information and communication technology • Information organisation - Types of documents • References records

\subsection{Information Literacy Concept}

Paul Zurkowski was the first to use the notion "information literacy". The American researcher states that persons with skills in information area are "educated people with the purpose of applying information resources in their work place" (Zurkowski 1974). The conceptual foundation was made by the American Library Association (ALA): "in order to have information literacy, a person needs to be aware of the information necessity, to be able to locate it, assess and use it efficiently. People acquainted with information literacy are those who learned how to learn" (ALA 1989). During the time from Paul Zukorwski-1974 until the 1989 definition given by ALA, the concept had some changes according to methods of information retrieval and represented the basis of intellectual work techniques. 
The American Library Association defines information literacy "as a set of abilities requiring individuals to recognize when information is needed and have the ability to locate, evaluate, and use effectively the needed information" (ALA 2018).

The Alexandria proclamation on Information Literacy and Lifelong Learning of 2005 states:

Information Literacy lies at the core of lifelong learning. It empowers people in all walks of life to seek, evaluate, use and create information effectively to achieve their personal, social, occupational and educational goals. It is a basic human right in a digital world and promotes social inclusion of all nations. (IFLA 2005)

Lau et al. (2014) presented the concept of Information Literacy (Fig. 3.1. Concept of Information Literacy).

CILIP (UK) Information Literacy Group updated (April 2018) the definition of Information Literacy:

- Critical thinking and discernment;

- Reflects more nuanced definitions of recent years;

- Focus on context, individual agency, empowerment of citizens; and

- No generic sets of skills and abilities to be acquired.

Information literacy is the ability to think critically and make balanced judgements about any information we find and use. It empowers us as citizens to reach and express informed views and to engage fully with society. (CILIP Information Literacy Group 2018)

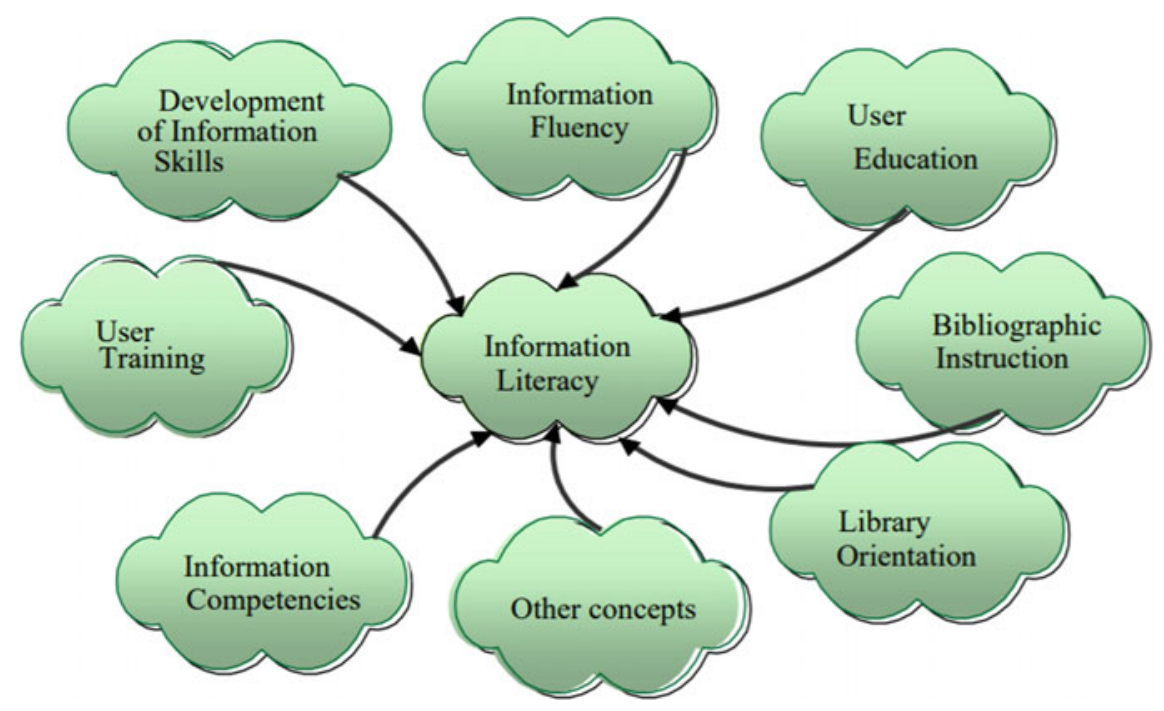

Fig. 3.1 Concept of information literacy (Lau 2014) 
Media and Information Literacy: "an important prerequisite for fostering equitable access to information and knowledge and promoting free, independent and pluralistic media and information systems.

CILIP: Central role of Information Literacy in reinforcing "democracy and civic engagement" (CILIP Information Literacy Group 2018).

\subsection{Equivalence of the Concept in Various Languages}

Information literacy was considered equivalent with the Romanian term of Cultura informaţiei. The equivalence of the concept information literacy from English in other languages is a difficult process, so information professionals from different countries should avoid semantic ambiguities. Thus:

- In German Medienkompetenz is used in respect of technical means of information identification and processing and Informationskompetenz is related to the correct perception and assessment of information;

- In French la culture de l'information or maîtrise de l'information means documentary-informational education (skills of documentary research);

- In Spanish "alfabetización informacional", a literal translation of the form "information literacy", is closely related to the "literacy" concept ("literacy training"), a term that is most people usually associate with basic skills like: reading, writing and arithmetic. We have here a semantic equivalence usually rejected by people. This is why, the term accepted today by Spaniards is "developing information skills and abilities" (DHI - desarrollo de habilidades informativas), a phrase that emphasises the overall process of information literacy, without referring to its primary point: literacy.

Ca01000043.schoolwires.net. (2018). [online] Available at: https://ca01000043. schoolwires.net/cms/lib08/CA01000043/Centricity/Domain/173/Brown_on_ Classroom_management.pdf. Accessed 8 Jul. 2018.

\subsection{Objectives of Information Literacy}

Education in information literacy is one of the priority objectives of the learning process. Information literacy consists of:

- Creating a thinking style that is appropriate to the demands of the contemporary information society expressed by information access capacity, analysis of the information environment and development of alternative information systems;

- Creating skills and working abilities with information sources; and 
- Independent solution for each problem by accessing, processing, storing and sending information.

\subsection{International Concerns on Information Literacy}

The International Federation of Library Associations and Institutions (IFLA) also includes, among its sections, an Information Literacy Section, as one of the most active and involved sections.

In The Alexandria Proclamation on Information Literacy and Lifelong Learning from November 2005, it is specified that: "[...] information literacy requires information competencies necessary for the recognition of information needs and to locate, evaluate, apply and create information in a determined cultural and social context; [...]".

United Nations Educational, Scientific and Cultural Organisation (UNESCO) developed a portal containing important information concerning events, conferences and lectures in this area. The following logo of Information Literacy was chosen by competition, Fig. 3.2 Logo used for Information Literacy.

\subsection{Competencies in Information Literacy}

A responsible citizen - a student or a professional - should be able to know the need of information, to locate information, identify, access, recover, evaluate, organize and use it. A person with information literacy is able to:

- prospect - the ability of locating the relevant information, of detailed and critical examination and selection;

- interpret - ability of transforming information and data into knowledge, insight and understanding; and

- create (new) ideas - ability of developing new cognitive perspectives (McKenzie 1986).

Fig. 3.2 Logo used for information literacy

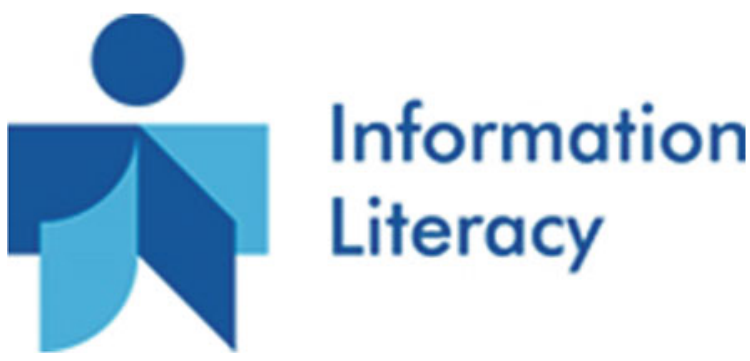




\subsection{Standards of Information Literacy}

\subsubsection{Structure of Standards}

The standards of information literacy include three basic components according to Figs. 3.3 and 3.4. Basic components of information literacy. Standards of information literacy established by IFLA, based upon international practice and experience are grouped within the three basic components of information literacy: accessing; evaluation; and use of information (Lau et al. 2014). Each of these has a certain significance:

- Information accessing - the user should access information in a sensible and efficient way;

- Information evaluation - the user should evaluate information in a critical and competent way; and

- Use of information - the user should use information in a correct and creative way.

In the evolution of IL components, new components have been found and added, such as: identify, find, evaluate, apply, and acknowledge information.

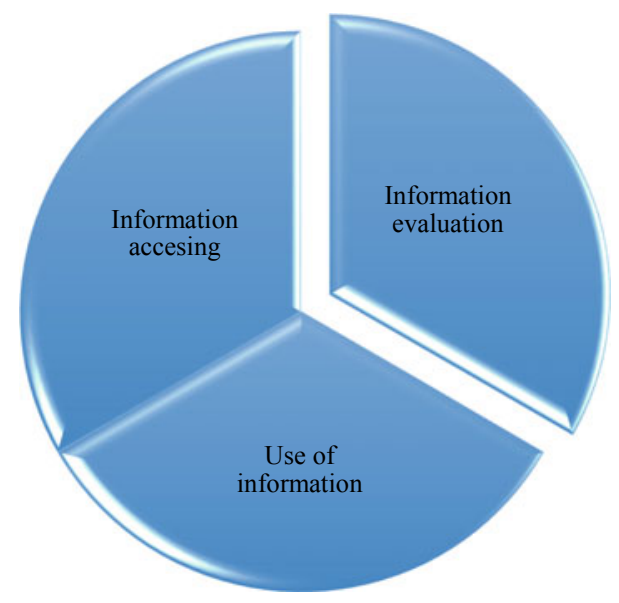

Fig. 3.3 Basic components of information literacy
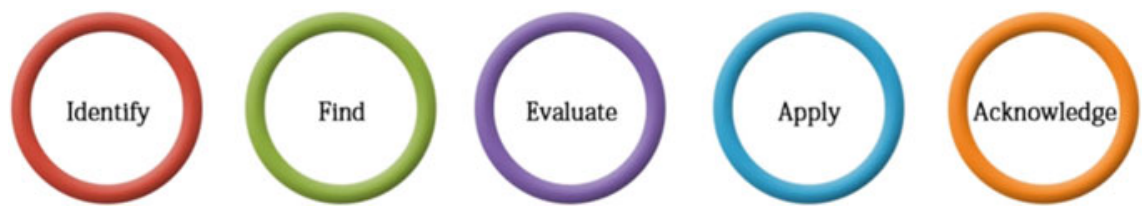

Fig. 3.4 Basic components of information literacy 


\subsubsection{International Standards of Information Literacy}

The first standards in information literacy were developed in the United States of America.

In 1998, the American Association of School Librarians (AASL) and Association of Educational Communications and Technology (AECT) published Standards for Pupils' Information Literacy (AASL 1998).

In 2000, the Association of College and Research Libraries (ACRL), which is part of ALA, adopted and published Information Literacy Competency Standards for Higher Education, 2000. This document establishes five standards to determine the level of information literacy for students. According to these standards, the student with a certain level of information literacy is able to:

- Determine the information type and quantity that he needs;

- Access the desired information in an effective and efficient way;

- Assess information and information sources in a critical way and assimilate the selected information into his knowledge and values system;

- Use the information for accomplishing a specific task, individually or within a group;

- Understand many of the economic, legal and social problems related to the use of information; and

- Use the information within the boundaries of ethics and legality.

For each of these categories, performance indicators and significant results are specified. The standards developed by ACRL are found in the ACRL manifesto, Information Literacy Standards for Higher Education: A Manifesto, Third Meeting on Information Competencies 2002 adopted at the third IFLA meeting for determining information skills in Mexico on 11 October 2002. The manifesto includes eight competencies in information literacy that involve several skills:

1. Understanding the structure of knowledge and information;

2. Determining required information profile;

3. Building an efficient strategy for information search and retrieval;

4. Getting information;

5. Information analysis and evaluation;

6. Information integration, synthesis, and use;

7. Presenting researched information; and

8. Observing copyright.

In July 2006, the IFLA section-Information Literacy, was published in final form in the guide called Guidelines for Information Literacy and Long-Life Learning (IFLA 2002). This guide has the purpose of creating a unique framework for professionals engaged with initiating a training programme for information literacy. The document is firstly addressed to libraries in education institutions, but 
can also be successfully applied in public libraries. It can be adapted and changed by librarians according to the needs and possibilities of their institution.

As far as the standards developed by ACRL are concerned, which group academic and research libraries, they insist on the concepts of "standard", "performance indicator" and "result", offering an efficient framework for evaluation. The user of information literacy follows these steps:

1. Defines the nature and context of the information he looked for. The performance indicators are:

- His capacity of focusing and identifying various types and formats of possible sources that could be useful;

- To consider the operation costs and benefits; and

- To reassess the nature and context of required information.

2. Accesses the information he needs, in an efficient and effective way. For this, the performance indicators are:

- The capacity of choosing the best investigation methods or the most adequate systems of "information retrieval";

- Building and implementing adequate research strategies;

- Retrieval of information online or otherwise using different methods;

- Improvement, if necessary, of the research strategy (at the end of this route); and

- Extracting, recording, and administration of information and sources.

3. Evaluates in a critical way the retrieved information and data sources including the data selected in his cognitive memory. The performance indicators are:

- Synthesising the main ideas extracted from retrieved information;

- Applying initial criteria for assessing both information and sources;

- Building new concepts starting from the main ideas;

- Comparing new knowledge with previous, in order to determine its validity;

- Comparing their own acquisition for a subsequent validation; and

- Determining if the initial hypothesis needs to be revised.

4. Uses the information in an efficient way, in order to accomplish a specific objective in time. Performance indicators are:

- Applying new information and that previously obtained, in planning and creating a certain product;

- Revising, in a critical way, the process with respect to the respective product; and

- Communicating the product to other information stakeholders. 
5. Understands many of the economic, legal and social issues, in context of use, informs and has access to information, being aware of social, economic, legal and moral elements. The performance indicators are:

- Understanding the moral, social, economic and legal elements, which represent a foundational basis in the world of information and TIC, as a consequence of laws, regulations and institutional policies related to information resource access and use; and

- Use of information sources in communication processes and their contribution to the final product.

\subsection{Models of Information Literacy}

There is a high number of research models and problem solving in information literacy. The most well known are: BIG6, Kuhlthau, The Seven Pillars Model, Research Cycle. Next, SCONUL, a model developed and updated in 2011 by the Society of College, National and University Libraries (SCONUL).

\subsubsection{SCONUL Model}

The model resulted from reflection on professional practice of those involved in developing information capacities within scientific communities. It is irrelevant whether the user has access to a virtual library via a computer or access to a physical library, or whether the user is a child doing his homework or a university professor; the model should cover all contexts. Still it is important to address the connection between the model and obtaining knowledge in universities. Consequently, due to its genesis, the SCONUL model became more important relative to other models. A schematic form of the SCONUL model is shown in Fig. 3.5 SCONUL model of Information Literacy.

These are seven basic competencies and their components (SCONUL 2001):

1. Ability to recognise an information need.

2. Ability to distinguish ways in which "lack" of information can be addressed:

- Knowledge of appropriate type of resources, both printed and unprinted;

- Selection of most appropriate resources; and

- Ability to understand issues that affect the sources accessibility. 
Fig. 3.5 SCONUL model of Information literacy

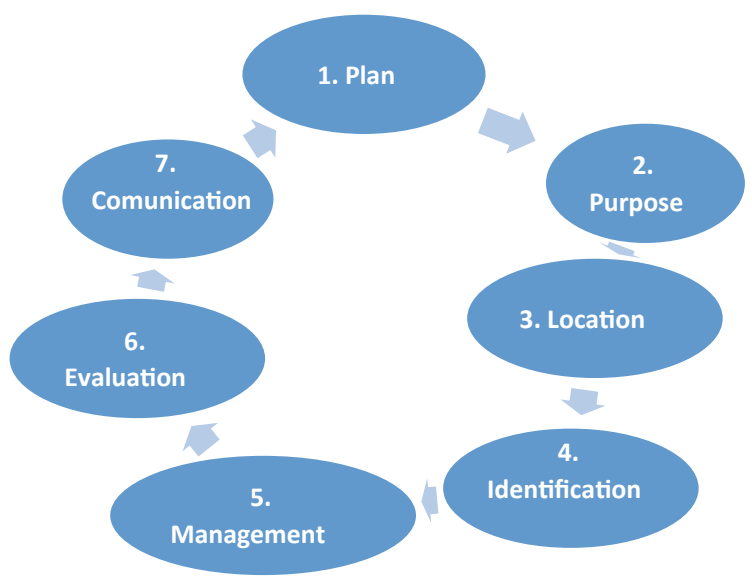

3. Ability to build strategies in order to locate information:

- To develop a systematic method adequate to the need; and

- To understand the principles of database construction and generation.

4. Ability to locate and access information:

- To develop appropriate search techniques;

- To use information and communication technologies, including international academic networks;

- To use appropriate indexing and abstracting services and citation databases; and

- To use current information methods.

5. Ability to compare and assess information obtained from different sources:

- Understanding the issues related to authority;

- Understanding the reviewing process in scientific publishing; and

- Appropriate extraction of information that corresponds to information need.

6. Ability to organise, apply and communicate the information to other people in ways appropriate to the situation:

- To cite the references in projects or theses and such like;

- To build a personal bibliographic system;

- To effectively communicate using the appropriate means; and

- To understand issues related to copyright and plagiarism.

7. Ability to synthetise and build based upon existing information and contribute to create new knowledge. 


\subsubsection{CILIP Information Literacy Model}

CILIP have developed an information literacy model that contains eight competencies or understandings that a person requires to be information literate:

- A need for information;

- The resources available;

- How to find information;

- Need to evaluate results;

- How to work with or exploit results;

- Ethics and responsibility of use;

- How to communicate or share findings; and

- How to manage findings (Infolit.org.uk 2018).

\subsubsection{Seven Faces of Information Literacy in Higher Education}

This model was developed by Christine Bruce (Bruce 1997).

Category one: information technology appreciation.

Information literacy is seen as using information technology for information retrieval and communication.

Category two: information sources appreciation.

Information literacy is seen as finding information located in information sources. Category three: information process appreciation.

Information literacy is seen as executing a process.

Category four: information control appreciation.

Information literacy is seen as controlling information.

Category five: knowledge construction appreciation.

Information literacy is seen as building up a personal knowledge base in a new area of interest.

Category six: knowledge extension appreciation.

Information literacy is seen as working with knowledge and personal perspectives adopted in such a way that novel insights are gained.

Category seven: wisdom appreciation.

Information literacy is seen as using information wisely for the benefit of others.

\section{Teaching Tips/Teaching Suggestions}

This learning unit, being an introductory course, requires a special teaching organisation. The purpose of such a course is to provide an overview on the field addressed and to prepare learners for better reception of information to facilitate deep learning. 
Although active and inquiry based learning are essential aspects of developing information literacy (Secker and Coonan 2011), a distinct feature of this course is to give greater attention to the formation of an appropriate teaching relationship with learners and to conduct an initial informal assessment, as a basis for changes made to the initial didactic design.

One of the most important pedagogical principles is the appropriateness of the formative approach to the particularities and specifics of a learning group. Knowing the level of scientific training, of pre-requisites, the level of expertise in the IL, and of their interests and expectations fundamentally alters didactic design.

Therefore, our recommendation is to give more time than in a typical course to stages such as: acquainting oneself with others and to initial verification of knowledge. Learners should be informed about the purpose of the initial evaluation, explaining the importance of knowing their current level of knowledge in designing a pedagogical approach appropriate to their learning needs.

These two stages can be designed as distinct activities or merged into the same pedagogical sequence. If we were to consider a combination of the two stages, the ideal would be, after a very brief presentation by the teacher, to provoke a dialogue, a conversation between all the participants. The rules of this conversation could be the following:

1. Each speaker should introduce himself before he speaks; and

2. Everyone should wait for the person who is already engaged to finish speaking.

The questions that will be asked will address the very purpose of IL and will use the main question forms: WHAT? WHO? WHY? WHERE? WHEN? Presenting the necessity and timelines of IL education in the formation of students' competences is a natural requirement of this stage. The Starburst Explosion Method, explained in Chap. 10 of this volume, can be used for this purpose.

If we design the two stages as distinct activities then at the stage of capture attention/warm up, a game can be used to animate the group. We realise that a group has a particular psychology that is different from that of an individual. Specialists and teachers consider it ideal to have 8-25 people for an educational activity, and that it is a significant factor to improve student learning (Watson et al. 2017).

For a newly formed group to work at an optimal level, it is necessary to set rules for the group from the first lesson. Ideally, these rules should not be imposed by the teacher but negotiated by the group members and built together with the trainer. The reason behind this recommendation is that if the rules are negotiated then they can be accepted and assumed more easily, if and where needed, avoiding, as much as possible, factors that could disrupt the didactic activity.

A natural question that any trainer would formulate is: On what criteria do I decide whether I will design an activity in which the two steps will merge or be separated?

One of the most relevant criteria, not excluding others, is the development phase at which the group is. If the group has been constituted for a long time then we 
assume they know each other and that certain relationships have already developed. Thus, it is pointless to insist on some aspects, which may be disregarded or categorised as unhelpful in carrying out the teaching and learning activity.

If the group is not homogeneous and was recently constituted then animation games are more than welcomed, as they facilitate the relaxation of the participants, creating a pleasant, secure, and stimulating climate for the group's activities.

The authors recommend the use of self-presentation games, which should not exceed $15 \mathrm{~min}$. Specialty literature abounds in variants of these types of games from which the reader can choose the most appropriate activity. We only insist on some form aspects such as: the seating of the participants, and the order of talking.

If space permits, it would be preferable for participants to be seated in a circle, to facilitate the view of each participant and to establish a position of equality among the members of the group. We recommend that the group leader as well, the teacher or the librarian, should be a part of the circle.

The trainer will: initiate the activity, announce its purpose, briefly describe the manner in which the activity will develop, present the time allocated to each participant; and state the estimated duration of the activity. In order to facilitate the task of the trainees, and to provide a model, the trainer will begin to introduce himself by saying his name and a few personal things about him, slipping something fun in the presentation in order to make participants feel more comfortable. Also, the trainer can highlight the link to IL. After finishing, he will invite participants to continue, allowing anyone to introduce himself.

If we want to avoid the situation in which none of the trainees have the courage to continue, we can use a ball to throw to a participant, who will have the obligation to continue. If we want to use a string of twine, the trainer will tie a finger with some of the material, inviting the rest of the participants to do the same. At the end of the activity, the trainer will highlight the social network that was formed and will compare it to an information network, thus linking it to IL.

Ideally, we would have had the chance to learn the motivation and the area of interest of the trainees participating in this course. If we did not have this opportunity, we can design a distinct activity in which the participants will reveal their goal for choosing the course. Expectations regarding the development of the course as well as individual motives can be freely discussed or set out on paper. Authors prefer the use of cards, which may even be anonymous, to allow even the shiest trainees to express their opinions.

\section{Adequate Teaching and Learning Methods}

The authors' choice is primarily the use of presentation methods for this first course. The arguments for this choice are:

1. Inter-recognition activities provided in the first part of the course are quite time consuming, but we need to give them the proper attention in order to determine the dynamics required for a successful course in the future; 
2. The activity, in which we learn the motivations and interests of learners, especially if it is done orally, can also be time consuming. If done in writing, we can start from the premise that not all participants reflected on these issues, thus, there is the possibility that 10 min will not be enough for any real insight;

3. Using the presentation methods in this course, we can prepare an appropriate set up, we can arouse the curiosity of the participants, highlighting the transdisciplinary role that IL has in academic and professional training but also in lifelong learning; and

4. Classical presentation methods, if they are used with craftsmanship, may facilitate the control of an environment, and a pedagogical context that may not be familiar to the participants. Thus, we can create a state of psychological comfort and ensure trainees' receptivity using the allotted time efficiently.

The main methods of teaching and learning, which we recommend for this course are: conversation, exposure, and lecture. All these methods are described in detail in Chap. 10, in the Presentation Methods section.

\section{Practice}

Fixing freshly acquired knowledge is a very important stage in the teaching process as it allows for the review of essential information, facilitating a hierarchy of this depending on its importance. This will enable learners to achieve a scaffold of knowledge, a logical scheme through which to organise their learning process.

A conceptual map is a very useful method at this case. It has the great advantage of being a graphical method allowing students with more dominant learning styles to utilise it. It is described in detail in Chap. 10 of this paper.

\section{Applications}

1. Discover and describe briefly another model of Information Literacy in the specialist literature.

Short description:

The main advantages of the model are:

Less clear issues: 


\section{Evaluation}

The KWL method is a teaching - learning method but also an evaluation method that helps a student to visualise the information that he has acquired in a certain didactic activity and to become aware of the need for information that is outlined in the light of new knowledge. It is a method that invites reflection, and facilitating the practice of metacognitive skills. Also, it is a tool that can also be used in other contexts, and educational disciplines. Generalising this manner of organising information, the student acquires a graphical formula of the learning process, applicable in various contexts. It is recommended that, before using this method, the trainer explain to students how to use it, exemplifying it with the current learning unit.

\begin{tabular}{c|c|c}
\hline K & W & L \\
(Knowledge $\quad \begin{array}{c}\text { learners } \\
\text { have about a given topic) }\end{array}$ & $\begin{array}{c}\text { (What learners want } \\
\text { to know more about) }\end{array}$ & \\
\hline & & \\
\hline & & \\
\hline & & \\
\hline & & \\
\hline & & \\
\hline
\end{tabular}

\section{References}

Alexandria Proclamation on Information Literacy and Lifelong Learning | United Nations Educational, Scientific and Cultural Organization, Unesco.Org. Accessed February 15, 2019. http://www.unesco.org/new/en/communication-and-information/resources/news-and-in-focusarticles/allnews/news/alexandria_proclamation_on_in.

American Association of School Librarians (AASL). (1998). Information power: Building partnerships for learning. Chicago, IL: AASL.

American Library Association. (2018). https://literacy.ala.org/information-literacy/. Accessed May 24, 2019.

Bruce, C. (1997). The seven faces of information literacy. Adelaide: Auslib Press.

CILIP. (2018). CILIP definition of information literacy 2018.

IFLA. (2005). https://www.ifla.org/publications/beacons-of-the-information-society-thealexandria-proclamation-on-information-literacy.

Lau, J. (2006). Guidelines on information literacy for lifelong learning. Boca del Río, Veracruz, México. Retrieved November 30, 2018, from http://archive.ifla.org/VII/s42/pub/ILGuidelines2006.pdf.

Lau, J., Bonilla, J. L., \& Gárate, A. (2014). Diving into deep water: Development of an information literacy rubric for undergraduate course syllabi. In S. Kurbanoğlu, S. Špiranec, E. Grassian, D. Mizrachi, \& R. Catts (Eds.), Information literacy. Lifelong learning and digital citizenship in the 21st century. ECIL 2014. Communications in Computer and Information Science (Vol. 492). Cham: Springer. https://doi.org/10.1007/978-3-319-14136-7_60 
Presidential Committee on Information Literacy: Final Report, American Library Association. (1989). http://www.ala.org/acrl/publications/whitepapers/presidential. Accessed May 18, 2019. SCONUL. (2001). The seven pillars of higher education. London: SCONUL.

Secker, J., \& Coonan, E. (2011). A New Curriculum for Information Literacy (ANCIL): curriculum and supporting documents. Cambridge: Cambridge University Library. Accessed on March 11, 2018 from http://openaccess.city.ac.uk/17370/1/ANCIL_final.pdf.

Watson, K., Handal, B., \& Maher, M. (2017). Class size: Teachers' perspectives. Curriculum and Teaching, 32(2), 5-26.

Zurkowski, P. G. (1974). The information service environment: Relationships and priorities. Washington, DC: National Commission on Libraries and Information Science.

\section{Webography}

ACRL. (2004). Information Literacy Competency Standards for Higher Education. Accessed July 12, 2018, from web site http://www.ala.org/ala/acrl/acrlstandards/informationliteracycompetency.htm.

Alair.ala.org. (2000). Information literacy competency standards for higher education. [online] Available at https://alair.ala.org/bitstream/handle/11213/7668/ACRLInformationLiteracy CompetencyStandardsforHigherEducation.pdf?sequence=1\&isAllowed=y. Accessed February $15,2019$.

American Association of School Librarians (AASL). (2006). About AASL. [online] Available at http://www.ala.org/aasl/about. Accessed July 13, 2018.

Association of College and Research Libraries. (2002). Information literacy competency standards for higher education. [online] Available at http://www.ala.org/ala/acrl/acrlstandards/ standardsguidelines.htm.

Association of College and Research Libraries. Information Literacy Competency Standards for Higher Education, 2002. [online] Available at http://www.ala.org/ala/acrl/acrlstandards/ standardsguidelines.htm. Accessed July 13, 2018.

Basic components of information literacy. (2019). https://libguides.seminolestate.edu/tutorials/ infolitcomponents.

Ifla.org. (2002). [online] Available at https://www.ifla.org/files/assets/information-literacy/ publications/ifla-guidelines-en.pdf. Accessed July 13, 2018.

McKenzie, A. (1986). Docs.Lib.Purdue.Edu. Accessed February 15, 2019. https://docs.lib.purdue. edu/cgi/viewcontent.cgi?article $=1106 \&$ context $=$ iatul.

\section{Bibliographic Recommendations: Definitions and Models- Information Literacy Website}

Infolit.org.uk. (2018). Definitions \& models-Information Literacy Website. [online] Available at https://infolit.org.uk/definitions-models/. Accessed July 8, 2018. 
Open Access This chapter is licensed under the terms of the Creative Commons Attribution 4.0 International License (http://creativecommons.org/licenses/by/4.0/), which permits use, sharing, adaptation, distribution and reproduction in any medium or format, as long as you give appropriate credit to the original author(s) and the source, provide a link to the Creative Commons license and indicate if changes were made.

The images or other third party material in this chapter are included in the chapter's Creative Commons license, unless indicated otherwise in a credit line to the material. If material is not included in the chapter's Creative Commons license and your intended use is not permitted by statutory regulation or exceeds the permitted use, you will need to obtain permission directly from the copyright holder.

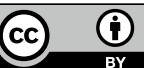

